\title{
Financial Innovation and its Governance: A Cross-case Analysis
}

\author{
Keren Naa Abeka Arthur \\ Centre for Entrepreneurship and Small Enterprise Development, University of \\ Cape Coast \\ Email: keren.arthur@ucc.edu.gh
}

\begin{abstract}
Over the past decades, financial innovation has catalysed the development of economies in many ways. Despite this, the introduction, commercialisation and use of innovations in finance in new and unexpected ways in society has led to negative impacts globally. To this end, scholars are becoming interested in understanding how financial innovations can be managed to ensure a positive net benefit globally. Using a qualitative research design, this paper investigates the questions of how innovation takes place and how it is governed within the insurance broking industry. The study further engages in a cross-case analysis where findings from the empirical work are discussed in relation to previous empirical study conducted in the asset management and bank customer relationship management space. Findings suggest the existence of a more nuanced continuum of practices, ranging from unstructured approaches through informal to formal models where the
\end{abstract}

phasing of innovation activities was clearly punctuated by decision gates.

Keywords: Financial innovation, innovation management and governance, financial services. 


\section{Introduction}

The concept of
responsible innovation has recently become an important topic in many sectors, including financial services. Within this field of study, researchers have sought to explore how financial innovators can organize, manage and govern their innovations in order to support a philosophy of responsible financial innovation. Nevertheless, studies are still limited with current research on the topic, focusing on what responsible financial innovation could mean theoretically (Armstrong et al., 2012; Muniesa \& Lenglet, 2013), how it plays out in varied empirical contexts (Asante et al., 2014; Himli, 2018; Arthur \& Owen, 2019) and efforts by governments to create regulatory frameworks that foster responsible financial innovation (MacDonald III, Ledbetter, Obie, Olson, Rodman \& Atherton, 2017). These studies have shown that there is a need to understand how financial innovation takes place and how it is governed in order to ensure its responsible emergence in society.

Results from empirical studies conducted by the researcher on financial innovation process and governance in the asset management and banking sectors (e.g. Asante et al., 2014; Arthur, 2017a; Arthur, 2017b; Khraisha \& Arthur, 2018; Arthur
\& Owen, 2019) show use of both formal and informal corporate governance mechanisms for financial innovation, often framed by contextual (rather than direct) legislation. This leads to the argument that the process and governance of financial innovation can vary across different sectors of the financial innovation landscape, which can be addressed by expanding research on the topic into other financial sectors. Therefore, the objective of this paper is to 1) investigate how financial innovation occurs and how it is governed in another financial context, specifically an insurance brokerage organisation; and 2) cross reference findings from the study on insurance brokerage with findings from empirical work earlier conducted by the researcher in two other financial sectors.

\section{Literature Review}

The Financial Innovation Process and Governance Framework

A review of the literature suggests that despite differences in the types of financial innovation (Finnerty, 1988, Finnerty, 1992, Graham \& Dodd, 1934, Tufano, 2003) and the number of activities within the innovation process (Edgett \& Jones, 1991, Vermeulen, 2004, Menor \& Roth, 2008), practices of idea generation 
and launch appear to start and end the financial innovation process respectively. The above studies suggest the use of an unstructured approach to innovation where complexity and incrementality is a feature. Financial innovations appear to be driven by a broad range of internal and external factors (e.g. client demand, institutional requirements, globalisation, technological advancements, competition and changes in regulation) (Llewellyn, 1992, White, 1997, Sánchez, 2010), which lead to new and improved products, processes, markets and institutions.

These are developed within a lead time averaging 12 months (Drew, 1995, Beard \& Dougan, 2004) and can involve both internal and external stakeholders (including management, board of directors, NPD and audit committees, selfregulatory bodies and government) (Erturk et al., 2004, Cohen et al., 2010) who interact with each other in an informal and unsystematic way (de Bretani, 1993, Sundbo, 1997, Vermeulen, 2004). Further, it is important to note that with the increasing use of open innovation in financial services (Schueffel \& Vadana, 2015), decentralised forms of governance (for example, the use of multiple people, such as software engineers, users, currency exchanges and regulators as well as automated systems in the governance of the virtual currency bitcoin) have emerged. This governance is, however, focused predominantly on governance of the financial sector as opposed to governance of financial innovation itself (Asante et al., 2014). The former monitored and enforced, using a variety of mechanisms that include legal codes, corporate governance frameworks, codes of conduct, internal controls, rules and periodic audits (Li et al., 2008, Panico et al., 2011). Further, governance mechanisms normally emerge through a process of issue identification, self-regulation, failure and legislation (Cox, 2008), where financial regulation only occurs after the occurrence of a negative event in the industry.

\section{Methodology}

The study adopts a qualitative research design. Within this design the study uses a multi-case study approach where research questions identified are investigated sequentially in three selected UK based organisations (see Table 1). These organisations were selected, using a purposive sampling approach, using a criterion of the organization having engaged in innovation in the past 5 years. Cases were also selected purposively from three different sectors of the financial services industry in the United 
Kingdom, namely asset management, banking and insurance, to allow for an understanding of the concept in varied contexts. Within case studies, the study used the organisational ethnography method, but chose to move away from the traditional long-term nature of ethnographic research (Neyland, 2007) by adopting the use of the "compressed time mode" approach proposed by Jeffrey and Troman (2004), which

"involved a short period of intense ethnographic research" in which the researcher inhabited the research site almost permanently" for a period of between three to six weeks (Jeffrey \& Troman, 2004, p.538) depending on organisation and access granted. Table 1 gives further details on this and shows use of ethnographic data collection methods, such as observation and interviews. 
Table 1: Summary of case studies selected

\begin{tabular}{|c|c|c|c|}
\hline Case & Category & Ethnographic Time & Data Collected \\
\hline Case 1 & $\begin{array}{l}\text { Financial firm } \\
\text { (Asset } \\
\text { Management) }\end{array}$ & $\begin{array}{l}\text { Six weeks in-house } \\
\text { Teleconferencing and } \\
\text { email follow-up over } \\
\text { period of six weeks }\end{array}$ & $\begin{array}{l}\text { - } 3 \text { semi-structured interviews with managers and } \\
\text { associates in the product development team } \\
15 \text { semi-structured interviews with managers and } \\
\text { associates in other departments involved in innovation and } \\
\text { its governance } \\
\text { Observation of } 3 \text { project management meetings } \\
\text { Observation of } 3 \text { steering committee meetings } \\
\text { Observation of } 1 \text { product review group meeting } \\
\text { Observation of } 1 \text { estimation and planning meeting } \\
\text { Observation of } 1 \text { idea generation and portfolia construction } \\
\text { meeting } \\
\text { Review of } 10 \text { internal document on the organization as a } \\
\text { whole, product development processes, and } \\
\text { documents/minutes of previous meetings held relating to } \\
\text { ongoing innovation project } \\
1 \text { face to face workshop conducted at the end of write-up } \\
\text { to validate findings }\end{array}$ \\
\hline Case 2 & $\begin{array}{l}\text { Technology-related } \\
\text { firm } \\
\text { (big data analytics) }\end{array}$ & $\begin{array}{l}\text { Three weeks in-house } \\
\text { Email follow-up via } \\
\text { email over a period of } \\
\text { six months }\end{array}$ & $\begin{array}{l}\text { - } 2 \text { semi-structured interviews with managers and associates } \\
\text { in the product team } \\
\text { - } 2 \text { semi-structured interviews with managers and associates } \\
\text { in the project management team } \\
\text { - } 11 \text { semi-structured interviews with managers and associates } \\
\text { in other departments involved in innovation and its } \\
\text { governance } \\
\text { - } 1 \text { semi-structured interview with external auditor } \\
\text { Observation of } 2 \text { update meetings } \\
\text { - Observation of daily employee activities } \\
\text { - Review of } 5 \text { internal documents on the organization as a } \\
\text { whole, product development processes etc. } \\
1 \text { face to face workshop conducted at the end of write-up to } \\
\text { validate findings }\end{array}$ \\
\hline Case 3 & $\begin{array}{l}\text { Financial firm } \\
\text { (Insurance broking) }\end{array}$ & $\begin{array}{l}\text { Three weeks in-house } \\
\text { Email follow-up via } \\
\text { email over a period of } \\
\text { four months }\end{array}$ & $\begin{array}{l}\text { - } 12 \text { semi-structured interviews with managers and associates } \\
\text { in departments involved in innovation and its governance } \\
\text { - Transcript of } 6 \text { short videos on innovation and the innovation } \\
\text { challenge on the organization's intranet site } \\
\text { - Observation of daily employee activities, including practices } \\
\text { at the Lloyd Insurance Market } \\
\text { - Review of } 20 \text { internal documents on the organization as a } \\
\text { whole, and on innovation mainly located on the } \\
\text { organization's intranet site and in hard copy } \\
\text { - } 1 \text { face to face workshop conducted at the end of write-up to } \\
\text { validate findings }\end{array}$ \\
\hline
\end{tabular}

Data collected were analysed, using the basic qualitative data analysis processes of reduction, data display and conclusion drawing/verification (Miles \& Huberman, 1994; Schutt, 2012). Data reduction was done as the researcher read through raw data multiple times to identify themes emerging from responses that served as codes for analysis.
Using open coding techniques, words, phrases and sentences in raw data were categorised based on the themes. This was followed by axial coding, which involved investigating similarities and differences within raw data themes and identifying relationships and patterns within open codes in order to identify broader emerging themes. Coded 
data were then displayed, using tables, graphs and diagrams, which allowed for an understanding of aggregate dimensions in order to draw conclusions. Data were presented, using a narrative approach that sought to synthesize findings from all data sources to tell the story of how innovation occurs and is governed.

\section{Description of Case Studies}

The first case study involved a large (global) and privately owned asset management company, whose activities involved the development and trading of investment funds (see Asante et al., 2014, for detailed results). Findings from this study suggested financial innovation to be largely incremental with short lead times and involvement of multiple stakeholders, managed within a well-structured stage-gate model of innovation governance in which the NPD teams played a co-ordinating role and in which there was a requirement for regulatory approval (in this case via the Financial Conduct Authority).

The second ethnographic study occurred in a much different organisational context in terms of size and operations - i.e. a small to medium-sized technology based organisation undertaking innovations to support big data analytics in the context of customer relationship management in the banking and retail sectors (see Arthur \& Owen (2019) for detailed results). Findings from this study showed the existence of a semi-formal stage gate model characterised again by short lead times and multiple (internal and external) stakeholder engagement. Both incremental and disruptive innovations were identified. In contrast to the first case, however, direct regulatory approval was not a feature of the innovation governance process, although laws from government (through the Information Commissioner's Office) and guidelines from the Payment Card Industry framed and influenced innovation pathways significantly. The third case study, reported in detail in this paper, turns to a global insurance broking company undertaking innovation associated with risk characterisation and placement in the financial sector. The paragraphs that follow present findings of the study conducted in the third case study and a cross-case analysis of findings from the three case studies.

\section{Results and Discussion}

Results for Case Study Three 
Innovation process and environment

The organisation in case 3 was observed not to have a separate research and development or new product development team and, as one of the respondents from the placement department put it, "no systematic process for, and champion of innovation exists within the organization." Nevertheless, innovation was observed to occur within business units, resulting, as described by the same respondent from the placement team, from the "motivation of a small group of individuals." New ideas sprung up spontaneously on an ad-hoc basis from within the organisation, which were then translated into innovations launched into the market, generally over a period of between 8 and 34 months, depending on, for example, whether risk governance approvals are required or not. Innovation was observed to be largely incremental and located in the process and product space. This involved either changes to policy wordings (in some cases the stripping of the policy to its bare minimum) and / or tailoring of already existing policies to client needs (hereafter referred to as "product innovation") as well as the creation of new processes and services to support and enhance the risk placement process (hereafter referred to as "process innovation").

Nevertheless, although incrementalism was the predominant mode of innovation exhibited in this study, this was not always the case.

While product innovations were driven by client demand, changes in regulation and findings from research on industry risk, process innovations were driven primarily by the desire to improve the way the organisation does business (e.g. broking and placement process) and gains competitive advantage by demonstrating to clients a good understanding of the industry and associated risks. These led to business model innovations as the output of changed internal processes that have created room for the organization to offer something new to carriers. There was no evidence of a formalised, structured corporate process for developing new products and services. Findings instead suggest a more ad-hoc, decentralized approach to the process and institutionalisation of innovation, despite the existence of corporate documents describing a closedloop innovation process, involving eight activities (industry verification, prioritisation, sector strategy refinement, business justification, product development, launch preparation, product launch and performance 
management). One respondent vaguely remembered the existence of a product development group in the past of about ten individuals within which he participated on a monthly basis.

Given the periodic, ad hoc, distributed and informal nature of innovation in the organization the researcher elected to adopt a historical approach in which she analysed the previous development of three major innovations (two product innovations within one business unit dealing primarily with financial institutions and one process innovation within another business unit overseeing global placement activities) in order to understand the organisational features of the innovation process and its governance. This analysis, which involved examining what the innovation was about, how it had developed overtime, who was involved and what mechanisms and tools were used, suggests four broad phases of innovation to be employed: idea generation; product/process design; launch preparation and launch - and just one informal approval point. These four phases did not constitute a formal, or even informal, innovation stage gating method, but rather a broad categorization of the key activities which related to new product/process development in the selected innovation cases.
Analysis of market offerings, in order to highlight gaps and identify opportunities for innovation, was found to be a significant driver for ideas. For example, one of the product innovations originated from gaps identified within conventional directors and officers (D\&O) policies regarding defence and/or legal representation expenses and the insight that most D\&O policies are too lengthy and cumbersome. This resulted in the introduction of an innovation that changed the way D\&O policies were written in order to make it simpler and provide clarity on issues identified. Another was a response to gaps in conventional crime policies, which were limited mainly to theft, specifically defined fraud activities and other types of losses, all of which led to litigation among insurers and clients. Again, this led to an incremental innovation that broadened the scope of crime policies in a way that did not pose excessive risk to underwriters. Similarly, the studied process innovation case stemmed from a desire to address the lack of a structured risk placement approach within the industry, which the organisation found necessary in order to support fastpaced decision making concerning which insurer is most suited to meet a client's needs. These gap analysis activities were conducted 
$\begin{aligned} & \text { predominantly by motivated } \\ & \text { individuals or groups of } \\ & \text { individuals within the } \\ & \text { organisation, } \\ & \text { independently from almost }\end{aligned}$
the organisation's operations and in a non-systematic way. Thus, one respondent argued that innovation within the organisation comes from two places: deep technical expertise and cross fertilisation between business units in a way that is not strategically mandated by the organisation. In the case of one of the product innovations studied, this gap analysis and idea generation was identified to have come from an individual's technical experience, prior to his joining the organisation. In other innovation example studied, although the gap analysis had been conducted within the organisation, this occurred among small groups of people as a side activity.

The product/process development stage of the innovation process involves the designing of the product/process on paper and the testing of this in the real world in order to confirm its feasibility. This, in common with idea generation, is also done by originators of the idea as a largely separate activity from routine business operations. However, it involves informal discussions with senior managers in the business unit who can consider, assess and challenge the idea. This process could also involve interactions with others (e.g. insurers and clients) in the industry. Of the product innovations that was studied, PD included the drafting of what the new policy would look like, followed by a series of face-toface, email and telephone discussions between originators and insurers, after the signing of a non-disclosure agreement, in order to stress-test its practicality (e.g. address the question of whether insurers are willing to underwrite the new risk and policy). By pointing out problems associated with simplifying a policy (using broad clauses for example), insurers were able to identify risks that were of concern to them, which the originators had overlooked; hence contributing to a process of co-designing of the product. In the case of the process innovation example, development involved a designing of the new process on paper and a small-scale testing of this in one of the organisation's offices. As explained by a representative from the risk management department, this stage should involve the preparation of a document that demonstrates a good understanding of what the idea is, how it feeds into the business unit's strategy as well as financial costs and projections. However, there was no evidence that this always occurs for all innovations on a systematic basis. 
The launch preparation phase serves as the point at which the organisation becomes formally involved in the innovation process. Following an informal approval by line managers and senior executives in the legal and compliance departments, ideas progress to a 'preparation to launch' stage. This consists of preparatory activities for roll-out rather than a build of the new product/service for most product innovations and is characterised by multiple interactions between business units and various departments. For process innovations, this phase could include technology design and build as funds need to be authorised for this to commence. In general, development activities involve selecting clients, carriers and any third-party technology vendors to work with (if required), fine-tuning marketing pitches, preparing proposals, finalising legal contracts, organising support materials (e.g. brochures, quick reference guides) and training employees. For the process innovation case studied, the researcher identified the use of tools such as the project management intranet site, monthly steering committee meetings, prioritisation and scoping review meetings, sign offs and workshops to govern engagements between business units and departments. However, according to one of the senior managers, the effectiveness of this engagement in maximising knowledge sharing was limited due to time constraints. As a result, he argued that there is room for improvement when it comes to stakeholder engagement within the innovation process at the organization.

Launch involves making new product/services available to the insured and carriers, or to employees within the organisation (if the new product or service is for internal use); and the commercialisation of this to others in the future. Commercialisation could be done in stages, with the organisation limiting the new product/service to specific clients, employees or regions. An example of this pragmatic approach to commercialisation was demonstrated in the case of one of the product innovations studied, where roll out to financial institutions was not undertaken until it had been launched and monitored in other non-financial industries for a period of time, as carriers perceived the financial sector as being too risky.

Innovation governance

Despite the lack of a formal, well-structured process for new product and process development, the existence a wellstructured risk governance model (Figure 1) was clearly apparent 
within the organization. This model was in development sometime before 2012; and a Financial Services Authority (now the Financial Conduct Authority (FCA)) censure leading to financial losses experienced by the organisation served to catalyse the existing efforts of the organisation in enhancing controls around bribery and corruption. It was observed that all new products and services within the organisation went through a rigorous risk governance process as the organisation believed that these had the potential to change its risk profile. Nevertheless, awareness of the existence of this governance mechanism was patchy, and most respondents lacked clarity in terms of what constituted a new product or service offering.
The risk governance process begins with the use of a decision-making tool to determine whether an idea will lead to a new product or service; and as such should go through the whole process. The decision-making tool is a one-page document defined by the organisation's board, which outlines ten characteristics of a new product or service. These characteristics include any idea that: leads to doing business in a new country or industry, involves high set-up cost (threshold determined by the board), requires the organisation to underwrite risks (according to exemption rules in FCA regulations giving insurance brokers an underwriting authority on behalf of an insurance carrier), and needs to be developed or delivered in conjunction with third parties, among others. 


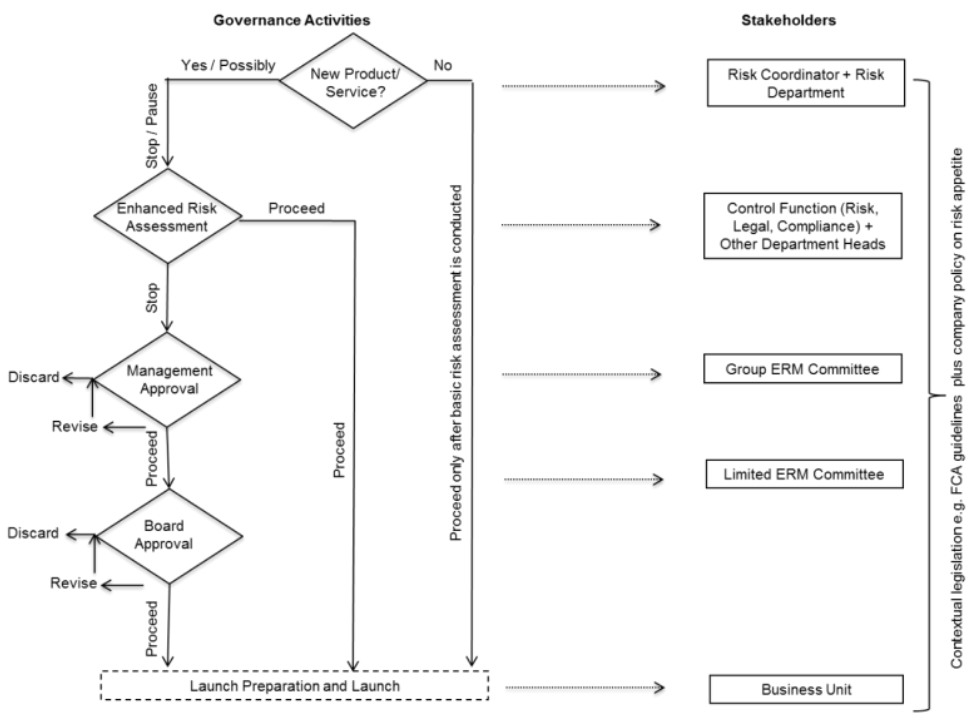

Figure 1: The Risk Governance Framework

New ideas that do not meet any of the criteria are clearly not considered new products or services and can, therefore, proceed with no formal approval required to launch preparation and launch, only after a basic risk assessment, which feeds into the existing business' risk profile has been conducted. For those ideas that are deemed to lead to new products/services, the $\mathrm{RCO}$ and risk function will make a decision for the idea to either pause or stop. The decision to pause is normally made for ideas that could possibly be a new product (e.g. meets at least one of the characteristics) and where there is deemed a need for further scrutiny and an enhanced risk assessment and challenge by control functions (e.g. risk, compliance, legal). The enhanced risk assessment stage, different from the workshops earlier described under risk assessment (on page 206) involves a series of round table sessions initiated by the risk function in collaboration with other departments e.g. compliance, legal, finance, and business leads among others (as needed based on the idea). Here, they discuss the idea to see if controls are genuinely in place and nothing has been missed. They challenge the idea based on the idea of conduct risk (i.e. risk emanating from the way the organisation and its 
employees conduct themselves) by asking questions such as: have we designed the product in the best interest of the client, how do we avoid confusion, are we relying on key persons for this to work, and, if we are, what happens if they are not available, among others. These questions suggest a broader framing of innovation governance than just risk, although the organisation themselves refer to the process as risk governance alone.

The output of this discussion leads to a decision concerning whether the idea should proceed to launch preparation and launch or stop. The stop decision normally applies to innovative ideas that are clearly new or significantly amended products or services (i.e. those that meet all or a significant number of the pre-defined characteristics) and means the innovator may continue to develop the idea internally but cannot conduct any external marketing, sales, communication and delivery of the product or service until an enhanced risk assessment, business plan development, and a review, challenge and approval of idea by a formal committee (i.e. management and the board) have been satisfactorily completed. Through what is referred to as the Group ERM Committee, senior managers of the organisation challenge the idea to see if it is fit for purpose, commercially viable, falls within the risk appetite of the organisation and provides a good risk/reward trade off. In the case of the placement process innovation, for example, a decision was made during the enhanced risk assessment stage to stop as the project was big and the initiators had to give an oral and written presentation on the business plan to the Group ERM committee. It is important to note that an idea would not be passed to the Group ERM committee without having first received robust challenge, including a review of business case and risks. This is followed by an independent risk review and challenge of the new product/service by the Limited's ERM Committee on behalf of the board of directors to check that management has an appropriate risk process in place, understands key risks, controls and impact on the organisation's risk profile, and these are within the risk appetite of the firm. New products/services approved at management and board levels go straight into investment and development. However, products/services that did not go to management and board approval because they were not considered significant by the risk function still need to undergo a risk assessment, incorporate views from compliance and legal 
departments and be passed by line managers for approval before they can be progressed. All ideas not approved at any stage of the risk governance framework are either revised to reflect the concerns raised by the governing committees and brought for further review later or discarded. In addition to the internal risk governance processes described above, contextual legislation also framed innovation in the company. Through the issuance of a license to operate from the FCA, the organisation was free to introduce any new products or service without the need for formal approval. However, the organisation believed that in the case of an innovation that was "material enough", FCA opinion was crucial prior to launch as the FCA retained the ability to intervene (for example by banning the use of a new product is found to pose some risks at a future date). The definition of what "material enough" meant was left to the discretion of the organisation's board.

\section{Discussion}

Definition, features and motivations

It was observed that innovation was largely framed across the case studies as either a "new" product or process, with limited explicit framing of innovation in the positionparadigm dimensions, as presented by Tidd et al. (2005) and Tidd and Bessant (2009). In terms of new products and processes, this was primarily presented as improvements to existing products and processes; and this was demonstrated through the largely incremental nature of innovation activities within all three cases. However, positional, and (paradigm changing) disruptive innovations were also a distinct feature of case study two, where, in addition to incremental innovation, the practice of positional and disruptive innovations was clear. This deviation may be due the low organisational age and small size of the organisation, in comparison to the others, as Assink (2006: 215) argues that such organisations may have no need to "unlearn obsolete mental models, a successful dominant design or business concept," thereby increasing their disruptive innovation capability with the right amount of risk-taking, innovation process management and follow-through in place. Further, the organisation in case study two appeared to be exposed to more opportunities for disruptive innovation as its operations were focused on and within an emerging industry (i.e. big data analytics) as opposed to well-established industries (i.e. 
asset management and insurance); which they could take advantage of, given limited regulation and a desire not only to grow, but also to strategically place itself in the market, being a start-up company. Regarding motivations and drivers, the researcher found in all three cases the use of financial innovation as a differentiation strategy to address the desire of the companies to survive, thrive and win in a competitive environment. This supports findings from the literature on the impact of competition in driving innovation initiatives in the 21 st century and could reflect the fast-paced nature of the financial sector and the potential for innovations to be easily copied (Tufano, 1989; Heffernan et al., 2013). Nevertheless, the argument for financial innovation as a needbased activity still holds as all three organisations recognised that the success of their innovation projects depended to some extent on external factors such as client demand and buy-in. Thus, findings from research on changing trends in consumer behaviour and interests were important drivers in the idea generation stage of the innovation process. Only in case study two was there evidence of innovation as a direct response to regulatory changes. However, the influence of contextual legislation and other forms of governance in all three cases compelled the organisations to consider the purpose (specifically their suitability for clients) and nature of their innovations at an early stage of the innovation process, and this provided important framing, and boundaries for innovation. Further, case study two also showed an impact of technological advancements in the pace of financial innovation activity as its innovations were, to some extent, catalysed by advances in information and communication technologies regarding data collection and analysis (e.g. Hadoop, NoSQL). In total, the researcher observed similarities with regard to the definition, features, and motivations (drivers) of financial innovation in all three cases; most of which support findings from the literature earlier discussed, such as the largely incremental nature of financial innovation driven primarily by factors such as competition, customer changing needs, and regulation.

An innovation management continuum: from linear to unstructured, non-linear models Findings from the literature suggested the lack of direct, formal innovation governance (regulatory or otherwise) and little evidence of corporate strategic innovation 
management processes (e.g. those described by Tidd et al. (2005), Tidd and Bessant (2009) and others). By contrast, the researcher, in fact, observed the use of strategic innovation management models in two of the cases, involving the phasing of innovation activities and clearly defined decision gates, and in case three a risk governance model that applied to new product and process development. In case one this was clearly institutionalised in the company as an established, coordinated and formal innovation governance process. This process was similar to what Cooper (2008) refers to as the stage-gating model for innovation management. Cooper (2008, p.3) defines a stage-gate as "an operational map" characterized by "a series of stages and decision gates". However, there was considerable variation in the application of innovation management across the three cases.

The researcher identified the use of a formal or informal stage-gate model for innovation management only in cases one and two, where NPD stages were integrated with decision gates. A review of the literature (Phillips et al., 1999; Cooper et al., 2002; Ettlie \& Elsenbach, 2007; Cooper, 2008; Cooper, 2009; Srivastava \& Singh, 2012) suggests a trend towards modification of the traditional stage-gate model
(Cooper, 1990) in theory and practice in order to improve its efficiency; thus, leading to the addition of a discovery stage, which creates an innovation funnel for proactively exploring new ideas (Cooper, 2009). This pattern of either adding to or subtracting from the generic fivestage, five-gate model of scoping, business case, development, testing and launch (Cooper; 2009) was observed in the two cases, which used a stage gating methodology, since they varied the number and descriptions of phases in the traditional stagegating model.

Case one was characterised by a five-stage, fourgate process, involving activities of idea generation, testing, build, launch and post-launch review which was officially recognized and used within the organisation. This approach considers business case approval as a key governance activity (i.e. a decision gate), merges the scoping and discovery stage into one (i.e. idea generation) and conducts testing much earlier in the innovation process in contrast to the generic model (Cooper; 2009). On the other hand, case two revealed a five-stage, four-gate process of opportunity assessment, impact assessment, requirements and scoping, build and launch; but this was loosely structured and used in a relaxed, unofficial way, in 
contrast to the first case study. This may be because development of the process was still emerging and in its infancy at the time of study; although the ambition to standardise processes was an important feature identified within the organisation. Further, this model merges the scoping and business case phase (i.e. requirements and scoping) as well as the development and testing phase (i.e. build and testing) while at the same time dividing the discovery stage into opportunity and impact assessment respectively.

In contrast with the other two cases, in case three, the researcher observed a largely unstructured innovation process, involving activities of idea generation, development, launch preparation and launch. However, despite this, innovation was integrated with well-defined risk governance mechanisms that were in place more broadly within the company. This supports findings from a study by Aas et al. (2015) on innovation practices within production-intensive service firms which they explain to include some financial institutions like banks and insurance companies that rely heavily on information and communication technology. According to their study, these institutions have innovation processes that are flexible. Overall, findings from all three cases suggest that approaches to innovation management fall within an innovation management continuum, comprising, on one hand, formal linear approaches, such as the stage-gating model (Cooper, 1990), and, on the other hand, more unstructured, nonlinear mechanisms of trial and error, and experimentation (Sperry \& Jetter, 2009). Despite these variations, innovation activities in all three cases involved an assessment of ideas and the making of new product/process available to users, at the beginning and the tail end of the innovation process, respectively.

Ownership of innovation and associated roles

Within cases one and two, the researcher identified the use of two of the innovation governance models proposed by Deschamps (2012) - individual(s) or department(s) charged specifically with the responsibility of managing the innovation process and/or innovation steering committees and boards. In contrast to this, innovation activity in case three was not embedded in the organisational structure of the organisation with clear lines of responsibility (and as part of job roles) in terms of who should oversee its smooth progress. Thus, the organisation appeared to have adopted the "no one in charge 
model" which, according to Deschamps (2012), occurs when an organisation a) wants to encourage shared responsibility for innovation, b) needs time to temporarily manage internal restructuring activities and/or c) considers innovation unimportant to require formal governance mechanisms. Findings from the study in case three suggest the first as reason for this as the identified initiatives within the organisation to promote innovation (at least recently) and a number of innovations originating from individuals who informally take on the role of "innovation champions", in addition to their defined job roles, and without need to be mandated by the organisation. The researcher found that both product/project departments (in case studies one and two) as well as individuals (in case study three) assume an "innovation owner" status; however, they play different roles - the former being co-ordination, organising and managing resources for the successful completion of innovation projects and the latter a development role as they try to build and test prototypes that will allow them make a business case and win the support of the organisation.

Co-innovation and the multistakeholder nature of the innovation process
Results from the cases suggest an element of coinnovation (Lee et al., 2012) for all three cases, to varying degrees, where internal and external stakeholders (Brown \& Eisenhardt, 1995; Chesbrough, 2003; Berthon et al., 2007; Blazevic \& Lievens, 2008) collaborated with each other within the innovation process framework (Piller et al., 2011). This differs from, but is linked to, the concept of co-creation (Prahalad \& Ramaswamy, 2004; Hirano et al., 2013); and involves not only the creation of value with customers through personalised user experiences, but also engagements with a broader group of stakeholders (including customers) in the designing of products and services (Piller et al., 2011): this was particularly evident in case study two. Thus, co-innovation departs from earlier models of innovation where new products and services were created only by and within organisations (closed), extending to specific partner firms (collaborative), or between firms and other stakeholders through an eco-system (open), using these new ideas to create new values and experiences for customers (Lee et al., 2012). While internal stakeholders within all three cases primarily involved employees who participated in management, decision making and departmental 
activities throughout the innovation process, external stakeholders involved customers (both businesses and individuals), partner organisations, and governments (Greer \& Lei, 2012; Lee et al., 2012) who engaged with the organisation at different times and in different ways throughout the innovation process. However, stakeholder engagement was, overall, limited: the researcher found no evidence of engagements with broader stakeholders such as competitors, activists and special interest groups identified in innovation projects in other sectors. With regard to internal stakeholders, management involvement for cases one and two occurred throughout the innovation process while that for case three occurred only after a product had been designed, when some form of financial commitment was needed, usually prior to launch (Smith \& Reinertsen, 1998). On the other hand, interactions with external stakeholders for case one occurred quite early in the innovation process (i.e. at testing phase), while external participation for case two occurred throughout the innovation process and that for case three occurred mid-way during the product development level and later at the end after launch.
At the FEI, new ideas for all three cases initially originated from within the organisation through interactions between the innovation owner and other business units. However, in case study two new ideas also originated from business customers; and this was due to the outsourcing relationship that existed between the organisation and its clients. As new ideas for all three cases progressed from evaluation to testing and/or development, external input was added in a guarded (e.g. using non-disclosure agreements) but concrete, elaborate and structured fashion (Piller et al., 2011). This dialogue was facilitated, using methodologies whereby business customers and/or their representatives (e.g. consultants/professional advisers for case one) were explicitly asked to evaluate concepts and test prototypes; all of which led to the refinement of the final offerings (Piller et al., 2011). In contrast, individual customers (who were in case two also the end-users) only played a passive role at the FEI, with their involvement limited to the provision of information in an indirect way through the use of customer feedback retrieved from call centres, data analytics and market research (Fang, 2008; Carbonell et al., 2009); perhaps reflecting arguments in the literature on the unsuitability of 
some customers in contributing to the innovation process. Despite this, Arvanitis et al. (2015) suggest that the involvement of customers, especially lead users in the innovation process can be beneficial if the appropriate methods of interaction is used. At the back end of the innovation process (i.e. commercialisation) business clients were also engaged actively in the innovation process (Piller et al., 2011). In cases two and three, for example, the systematic nature by which commercialisation was done allowed the organisations to incorporate user feedback into existing offerings; thereby making available to new clients a refined version of launched new products/processes as the scope of commercialisation widened.

It was found that both business and individual customers were not involved to any significant degree in the actual build of the new product/services. However, partner organisations and government (through regulators) appeared to play an active role in the development stage of the innovation process, with little involvement at the front and back end stages. In cases two and three, partner organisations comprised several merchants and carriers respectively. Their involvement in the development phase of the innovation process stems from the fact that their services are crucial to the effective creation and approval/valorisation of the new product/process. Thus, major innovations developed in case two may not have been possible without the network of merchants to provide cash rewards, and the product innovation in case three may not have been viable without the availability of carriers willing to take on the risks specified in the new policy. Perhaps these partnering organisations could also be considered as suppliers (Kopecka et al., 2011) as they provide to some extent elements of the resources needed to effectively deliver the new product or process. These may be limited in terms of their input in the shaping of innovation; but they could be very important as their inability to deliver could significantly influence the innovation's success.

Regulatory and non-regulatory governance

In all three cases, the researcher found the existence of both internal and external stakeholders directly or indirectly involved in the innovation governance process. These were either regulators providing oversight of innovation and general business activity more broadly, or market participants who acted not only as the "regulated," but also oversaw the 
innovation process and how new products evolved from idea to launch (e.g. banks in case study two). Regulators (mainly external to the organisation) comprised the government who delegated to various enforcement agencies (e.g. tax authorities in case one, the financial conduct authority (FCA) in cases one and three, and the Information Commissioner's office (ICO) in case two) as well as a formalised Self-Regulatory Organisation (SRO) (i.e. the Payment Card Industry Security Standards Council), whose activities were mandated by industry and not government in case study two. Further, the activities of these bodies were supported by external auditors in cases one and two. While external auditing for innovation in case study one occurred post launch, that for case two happened independent of the innovation process and focused on adherence to general good business practices. Regarding internal stakeholders, the researcher's findings suggest the use of the universal corporate governance framework as a model of innovation governance. This is evidenced in the review, challenge and approval roles played by top management, board of directors, internal auditors and employees within specific departments of the organisation (e.g. product development, legal, risk and compliance) or its client's organisations (for case two and three where innovation involves a relationship web with multiple stakeholders) as part of the innovation process. The interests of shareholders were acknowledged in cases two and three as important; however, I found no evidence of their direct involvement in the innovation governance process.

These findings suggest that both contextual (and in case one direct) legislation (what Braithwate and Drahos (2000) referred to as state regulation) and self-regulation (what Braithwaite and Drahos (2000) referred to as corporate regulation) were important instruments of innovation governance in all three cases. This challenges the prevailing view in the literature that financial innovation is neither governed within companies or subject to external regulatory governance or industry standards. Nevertheless, it is important to acknowledge, as suggested strongly in the literature, that legislation in cases two and three appeared to relate to financial sector governance and not financial innovation governance per se. In contrast, findings from case one suggest the direct or formal (Braithwaite \& Drahos, 2000) intervention of government (through agencies) in innovation governance through regulatory approvals required prior to launch 
(for example submission of portfolio to the FCA for approval). Despite these differences, overall, the researcher found legislation, whether focused on financial activity relating to innovation or financial innovation itself, was an important influence that framed innovation activities, since regulatory guidelines (direct or indirect) create 'de facto' boundaries within which innovation activities could take place. Thus, self-regulation practices within all the three studied organisations were found to focus heavily on ensuring compliance to broader regulatory boundaries set by the legislator, or industry standards though these were quite flexible (Braithwaite \& Drahos, 2000). This indirect involvement of legislators in the innovation process was largely loosely structured, with engagement with the legislator in several different ways and at varying frequencies for different innovation projects. The intensity of engagement increased (i.e. beyond the standard monitoring visits to include additional discussions initiated by the organisation) in situations where there was lack of clarity of existing regulatory guidelines regarding emerging innovation pathways.

The researcher identified in case study three a strengthening of the effectiveness of existing, internal corporate policies through the introduction of new controls, mechanisms and incentives in response to failure (e.g. the establishment of a risk governance framework following a financial loss). These mechanisms were, in fact, found to extend to the other two cases to varying degrees to include committees, internal controls and codes of conducts. Comprising groups of individuals appointed by the organisation, committees engaged in discussions during periodic meetings in order to understand key issues related to the new product/process. These committees differed in purpose from the one identified in the literature i.e. as a mechanism used by government in financial regulation. Their activities focused either on evaluating and approving new products/processes throughout the innovation process (hereafter referred to as decisionmaking committees) or monitoring the progress of new products/processes from idea generation to launch (hereafter referred to as project management committees) as opposed to investigating issues and making recommendations for regulatory reform. The number of people on these committees varied in all three cases; however, it appeared that each of these committees involved representatives from different departments of the 
organisation. Decision-making committees in all three cases appeared to exist formally within the studied organisations; and these met at pre-set times. However, project management committees were only properly established in cases one and three. In case two, this reflected the informal and ad-hoc nature of interactions within and between departments, convened as necessary throughout the innovation process.

\section{Conclusion}

It is important not to generalise from the results of three case studies; the extent to which the findings are generalisable both more broadly within and beyond the asset management, customer relationship management and insurance brokerage sectors requires further research. Nevertheless, findings from three studies suggest similarities between innovation practices (and their governance) across the studied organisations and (with important differences) to dimensions described in the literature. These allow the researcher to, firstly, suggest a few amendments to the theoretical model of financial innovation described earlier based on the literature review. Findings from the three case studies appear to originate and emerge from the desire of organisations to meet customer needs, gain competitive advantage, and respond to findings from research in the industry and changing regulation. However, while the literature suggested that innovation generally follows an unstructured and informal innovation process, with little evidence of systematically used frameworks, findings from the empirical work, in fact, suggests a more nuanced continuum of practices, ranging from unstructured approaches through informal to formal models (e.g. stage-gate) where the phasing of innovation activities was clearly punctuated by decision gates.

Despite these differences, involvement of both internal and external stakeholders (e.g. clients, regulators and partners) mediated through an innovation owner (i.e. a department(s), individual or group of individuals) was a prominent feature of all three cases. These lead to the launch of primarily incremental (e.g. varying the characteristics of funds, changes to loyalty programme implementation phase and alterations to insurance policy wordings), and, on a few occasions, disruptive innovations, which can be mapped onto the product, process and positional innovation landscape (and in case two paradigm dimension). They occurred within relatively short lead times (normally between 3 
and 34 months), as suggested in the literature. Within this framework, government legislation and industry standards played a key role in setting the governance context and frame within which innovation activities take place; and these were enforced primarily through dialogue and approvals at key decision-making meetings, internal controls and codes of conduct.

Within the case studies, the researcher identified the existence of a range of mechanisms to foster anticipation, characterisation and management of risks associated with financial innovations. The extensive use of non-regulatory forms of governance mechanisms, such as project management and decisionmaking committees, provided a starting point for risks to be assessed and understood. This characteristic, which the research considers to be one of the strengths of the current financial innovation and governance model, was even present in organisations that used unstructured approaches to manage the innovation process, albeit these were not sufficiently integrated with innovation activity. What is of note is that this was largely restricted, knowingly or unknowingly, to the internal operations of the organisation, namely to activities associated with its internal stakeholders.
Further, although avenues for anticipatory deliberations were in place, discussions focused mainly on quite narrow definitions of (largely operational) risk (e.g. project specific risks such as cost and time overruns, organisational capacity to meet demand and financial returns, regulatory and reputational risks) with limited consideration of potential wider e.g. systemic impacts within the innovation governance framework itself.

The involvement of multiple stakeholders in the cocreation and governance process (to varying degrees) is another feature of the current framework for financial innovation and its governance that could help steer innovation towards desired ends. This feature not only allows for multiple perspectives on the issues at stake, but also engages individuals with the relevant knowledge, skill and technical expertise to help the organisation make strategic decisions (e.g. to attempt to distinguish beneficial innovations from harmful ones using outputs from anticipatory, reflective and deliberative exercises). Such individuals can also contribute greatly towards decisions regarding options for mitigation available to the organisation. Despite this strength within the current model, and except for case study two, the researcher identified engagement 
and deliberation to be largely limited when this came to external stakeholders. This is evidenced in practices of limited involvement of diverse stakeholder groups (where these differ from clients) and even in the context of clients, limited engagement of individual clients in the innovation process.

Overall, there was a distinct lack of communication and dialogue with, and amongst, a diverse range of external stakeholders. The few external stakeholders that are involved (e.g. customers/clients, partners firms, and regulators) are not brought together on one platform (e.g. as has been done in some innovation examples in science and technology studies through public debates and consensus conferences) to engage with each other on the issues at stake). Those external stakeholders who do engage do so through an innovation owner who collates all ideas and shares these with other internal stakeholders as and when these are needed. This may suggest a conscious or unconscious filtering of external stakeholder contributions and ideas by the innovation owner, which could limit the effectiveness of a more broadly configured deliberative process. Further, the innovation owner in this framework does not share with other external stakeholders the contributions of other external or internal stakeholders, thereby eliminating the option of mutual learning amongst a varied group of stakeholders.

This is quite an important gap in the current model as it suggests that deliberative processes identified within the case studies fall short of some of the good engagement practices suggested in the literature as being necessary for positive outcomes. Specifically, it suggests that the criteria of openness (which relates to diversity among stakeholders), level of intensity (relating to the timing and nature of engagement) and quality (with regard to number of engagements and the mechanisms in place to facilitate engagements) are lacking. This all presents as a lack of engagement with a wide range of external stakeholders, which might include such groups as competitors, activists and special interest groups all of whom could provide important contributions to understanding the wider impacts, and social desirability of innovations in the financial sector.

The use of formal or informal linear innovation management models, such as the stage-gate model identified in some of the organisations, provides an opportunity for an ongoing monitoring and assessment of innovation activities, thereby allowing the organisations to respond quickly. 
Despite this, overall, the researcher often observed a lack of a systematic approach to collecting and screening ideas across the cases. That said, tools such as periodic meetings, internal controls (e.g. documents, checklists, automated rules, contracts, etc.) and codes of conduct, not only encouraged responsiveness to emerging knowledge on risks and broad impacts, but also served to incentivise positive action among stakeholders. One question the study begs is whether the degree of formalisation of innovation processes and governance described has any positive impacts on innovation capability and outcomes. Further, although the involvement of multiple stakeholders in the financial innovation process implies broader scope for co-creation and deliberation, it has the potential to introduce complexity regarding stakeholder relationship and participation management, especially in cases where structured governance approaches are absent. Thus, there is a need to clearly map out who the stakeholders are, what their roles are and possible channels of communication to ensure that the experience and outcomes are positive. 


\section{References}

Arvanitis, S.B., Fuchand, M. \& Woerter, M. (2015). Opening up the innovation process: outside-in involvement of innovative users and established firms' innovation performance. International. Journal of Innovation Management, 19(2), 1550029

Armstrong, M., Cornut, G.S.D., Lenglet, M.., Millo, Y., Muniesa, F., Pointierand, A., \& Tadjeddine, Y. (2012). Towards a practical approach to responsible innovation in finance: New Product Committees revisited. Journal of Financial Regulation and Compliance, 20(2). 147168

Asante, K., Owen, R., \& Williamson, G. (2014). "Governance of new product development and perceptions of responsible innovation in the financial sector: insights from an ethnographic case study". Journal of Responsible Innovation, 1(1), 9-30.

Arthur, K.N.A. (2017). The emergence of financial innovation and its governance: A historical literature review. Journal of Innovation Management, 5(4)

Arthur, K.N.A. (2017). Financial innovation and its governance: Cases of two major innovations in the financial sector. Financial Innovation, $3(10)$.

Arthur, K.N.A., \& Owen. R. (2019). A microethnographic study of big data-based innovation in the financial services sector: Governance, ethics and organisational practices, Journal of Business Ethics, https://doi.org/10.1007/s 10551-019-04203-x

Assink, M. (2006). Inhibitors of disruptive innovation capability: A conceptual model. European Journal of Innovation Management, 9(2), 215 233.

Beard, C., \& Dougan, S. (2004). Winning New Product Development Strategies in Financial Services: Building a Profitable Culture for NPD Success.London: Business Insights Ltd.

Berthon, P.R., Pitt, L.F., Mccarthy, I. \& Kates, S.M. (2007). When customers get clever: Managerial approaches to 
dealing with creative consumers. Business Horizons, 50(1), 39-47.

Blazevic, V., \& Lievens A. (2008). Managing innovation through customer coproduced knowledge in electronic services: An exploratory study. Journal of the Academy of Marketing Science, 36(1), 138-151.

Braithwaite, J., \& Drahos, P. (2000). Global Business Regulation.Cambridge:

Cambridge University Press.

Brown, J.S., \& Eisenhardt, K.M. (1995). Product development: Past research, present findings, and future directions. The Academy of Management Review, 20(2), 343-378.

Callon, M., Lascoumes P., \& Barthe, Y. (2010). On Acting in an Uncertain World: An Essay on Technological

Democracy.Boston, MA: MIT Press.

Carbonell, P., RodriguezEscudero, A., \& Pujari, D. (2009). Customer involvement in new service development: An examination of antecedents and outcomes. Journal of Product Innovation
Management, 26(5), 536550.

Chesbrough, H.W. (2003). Open Innovation: The New Imperative for Creating and Profiting from Technology, Boston, MA: Harvard Business School Press.

Cohen, J., Krishnamoorthy, G., \& Wright, A. (2010). Corporate governance in the post-sarbanes-oxley era: Auditors' experiences.

Contemporary

Accounting Research, 27(3), 751-786.

Cooper, R.G. 1990. Stage Gate Systems: A New Tool for Managing New Products. Business Horizons, 33, 44-54.

Cooper, R.G. (2008). Perspective: The stage-gate ${ }^{\circledR}$ idea-tolaunch process - update, what's new, and nexgen systems. Journal of Product Innovation Management, 25(3), 213232.

Cooper, R.G. (2009). How companies are reinventing their ideas-tolaunch methodologies. Research Technology Management, 52(2), 4757.

Cooper, R.G., Edgett S.J., \& Kleinschmidt, E.J. (2002). Optimizing the 
stage-gate process: What best practice companies are doing - Part One. Research Technology Management, 45(5), 1-9.

Cox, D. (2008). Financial services regulation and corporate governance. In: A.Tarantino (ed.) Governance, Risk, and Compliance Handbook: Technology, Finance, Environmental, and International Guidance and Best Practices. New Jersey: John Wiley \& Sons.

de Brentani, U. (1993). The new product process in financial services: Strategy for success. International Journal of Bank Marketing, 11(3), 15-22.

Deschamps, J.P. (2012). The Nine Models of Innovation Governance. Lausanne, Switzerland:

International Institute for Management

Development.

Drew, S.A.W. (1995). Strategic benchmarking:

Innovation practices in financial institutions. International Journal of Bank Marketing, 13(1), 4 - 16.

Edgett, S., \& Jones, S. (1991). New Product development in the financial service industry: a case study. Journal of Marketing Management, 7(3), 271-284.

Erturk, I., Froud, J., Johal, S., \& Williams, K. (2004). Corporate governance and disappointment. Review of International Political Economy, 11(4), 677-713.

Ettlie, J.E., \& Elsenbach J.M. (2007). Modified stagegate ${ }^{\circledR}$ regimes in new product development. Journal of Product Innovation Management, 24(1), 20-33.

Fang, E. (2008). Customer participation and the trade-off between new product innovativeness and speed to market. Journal of Marketing Management, 72(4), 90104.

Finnerty, J.D. (1988). Financial engineering in corporate finance: An overview. FM: The Journal of the Financial Management Association, 17(4), 14-33.

Finnerty, J.D. (1992). An overview of corporate securities innovation. Journal of Applied Corporate Finance, 4(4), 23-39.

Flynn, M., Dooley, L., O’Sullivan, D., \& Cormican, K. (2003). Idea management 
for organizational innovation. International. Journal of Innovation Management, 7(4), 417442.

Gioia, D.A., Corley, K.G., \& Hamilton A.L. (2012). Seeking qualitative rigor in inductive research: Notes on the Gioia methodology.

Organizational Research Methods, 16(10, 15-31.

Graham, B., \& Dodd, D. (1934). Security Analysis, New York: McGraw Hill.

Greer, C.R., \& Lei, D. (2012). Collaborative innovation with customers: A review of the literature and suggestions for future research. International Journal of Management Reviews, 14(1), 63-84.

Hering, D., \& Phillips, J. (2005). Innovation Roles: The People You Need for Successful

Innovation. Virginia:

NetCentrics Corporation. Hopkins, M.M., Tidd, J., Nightingale, P. \& Miller, R. (2011). Generative and degenerative interactions: positive and negative dynamics of open, usercentric innovation in technology and engineering consultancies. $R \& D$
Management, 41(1), 4460.

Jeffrey, B., \& Troman, G. (2004). Time for ethnography. British Educational Research Journal, 30(4), 535-548.

Khraisha, T., \& Arthur, K.N.A. (2018). Can we have a general theory of financial innovation processes? A conceptual analysis. Financial Innovation, 4(4)

Koen, P.A., Ajamian, G.M., Boyce, S., Clamen, A., Fisher, E., Fountoulakis, S., Johnson, A., Puri, P., \& Seibert, R. (2002). Fuzzy Front End: Effective Methods, Tools, and Techniques. In: Belliveau, P., Griffen, A. and Sorermeyer, S. (eds.) PDMA Toolbook for New Product Development. New York: John Wiley and Sons.

Kopecka, J.A., Santema, S.C. \& Hultink E.J. (2011). Supplier involvement in new product development: The preferred supplier from the purchasing, engineering and supplier perspective. 18th International Product Development Conference.

Delft, Netherlands. 
Kim, J., \& Wilemon, D. (2002). Strategic issues in managing innovation's fuzzy front-end.

European Journal of Innovation Management, 5(1), 27-39.

Lee, S.M., Olson, D.L. \& Trimi, S. (2012). Co-innovation: convergenomics,

collaboration, and cocreation for organizational values. Management Decision, 50(5), 817-831.

Li, C., Rupley, K.H., \& Johnstone, K. (2008). Internal governance, external governance and internal control mateiral weaknesses remediation. Social Science Research Network Working Paper Series, 1091685.

Llewellyn, D. (1992). Financial innovation: a basic analysis. In: Cavanna, $\mathrm{H}$. (ed.) Financial Innovation. London: Routledge.

Menor, L.J., \& Roth, A.V. (2008). New service development competence and performance: An empirical investigation in retail banking. Production and Operations Management, 17(3), 267-284.

Miles, M.B., \& Huberman, A.M. (1994). Qualitative Data
Analysis: An Expanded

Sourcebook, Thousand

Oaks, CA: Sage.

Muniesa, F., \& Lenglet, M. (2013). Responsible Innovation in Finance: Directions and Implications. In: Owen, R., Bessant, J. and Heintz, M. (eds.) Responsible Innovation: Opening up Dialogue and Debate.

Neyland,

D. (2007).

Organizational

Ethnography, London: SAGE Publications.

Owen, R., Stilgoe, J., Macnaghten, P., Gorman, M., Fisher, E., \& Guston, D. (2013). A Framework for Responsible Innovation. In: Owen, R., Bessant, J. and Heintz., M. (eds.) Responsible Innovation: Managing the Responsible Emergence of Science and Innovation in Society.Chichester: Wiley.

Panico, C., Pinto, A., \& Anyul, M.P. (2011). A critical approach to the analysis of the evolution of financial regulation before and after the crisis. Conference celebrating the 70th anniversary of review Investigacion Economica. Mexico.

Phillips, R., Neailey, K., \& Broughton, T. (1999). A 
comparative study of six stage-gate approaches to product development. Integrated

Manufacturing Systems, 10(5), 289-297.

Piller, F.T., Ihl, C., \& Vossen, A. (2011). Customer cocreation:

Open innovation with customers. A typology of methods for customer cocreation in the innovation process. In: Wittke, V. and Hanekop, H. (eds.) New Forms of Collaborative Innovation and Production on the Internet: An interdisciplinary

perspective. Göttingen,

Germany:

Universitätsverlag

Göttingen.

Poskela, J. (2007). Formalization of the Front-end Phase of the Innovation Process Competitive Advantage or a Path to Downfall? The 10th International Conference Society for Global Business \& Economic Development (SGBED): Creativity and Innovation: Imperatives for Global Business and Development. Kyoto, Japan.

Reid, S.E., \& de Brentani, U. (2004). The Fuzzy Front End of New Product
Development for Discontinuous Innovations:

A Theoretical Model. Journal of Product Innovation Management, 21(3), 170-184.

Sánchez, M. (2010). Financial Innovation and the Global Crisis. Canadian Center of Science \& Education.

Schueffel, P.E. \& Vadana, I. (2015). Open Innovation in the Financial Services Sector - A Global Literature Review. Journal of Innovation Management, 3(1), 25-48

Schutt, R.K. (2012). Investigating the Social World: The Process and Practice of Research, Thousand Oaks, CA: SAGE Publications.

Selko, A. (2008). Formalized Innovation is Competitive Advantage. IndustryWeek [Online]. Available at: http://www.industryweek .com/companies-ampexecutives/formalizedinnovation-competitiveadvantage, accessed on 17 October 2015.

Smith, P.G., \& Reinertsen, D.G.(1998). Developing Products in half the time - New rules, new tools, Canada: John Wiley \& Sons, Inc. 
Sperry, R., \& Jetter, A.J. (2009). Theoretical Framework for Managing the Front End of Innovation under Uncertainty. Proceedings of PICMET 2009: Technology Management in the Age of Fundamental Change. Portland, OR.

Srivastava, S., \& Singh, D. (2012). Modifying stage-gate product development process with the application of customer perceived value components.

International Journal of Research in

Management, Economics and Commerce, 2(11), 106-126.

Sundbo, J. (1997). Management of innovation in service. Service Industries Journal, 17(3), 432-455.

Sykes, K., \& Macnaghten, P. (2013). Responsible Innovation - Opening Up Dialog and Debate. In: Owen, R., Bessant, J. and Heintz, M. (eds.) Responsible Innovation: Managing the Responsible Emergence of Science and Innovation in Society.Chichester: Wiley.

Tidd, J., \& Bessant, J.R. (2009). Managing innovation: integrating technological, market and organizational change. Chichester: John Wiley.

Tidd, J., Bessant, J.R. \& Pavitt, K. (2005). Managing innovation: integrating technological, market and organizational change. Chichester: John Wiley.

Tufano, P. (1989). Financial innovation and firstmover advantages. Journal of Financial Economics, 25(2), 213240.

Tufano, P. (2003). Financial Innovation. In: Constantinides, G. M., Harris, M. and Stulz, R. M. (eds.) Corporate Finance. Amsterdam, The Netherlands: Elsevier Science and Technology Books.

Vermeulen, P. (2004). Managing product innovation in financial services firms. European Management Journal, 22(1), 43-50.

White, L.J. (1997). Technological change, financial innovation and financial regulation in the U.S.: The challenges for public policy. In: Harker, P. T. and Zenios, S. A. (eds.) Performance of Financial Institutions: Efficiency, 
Innovation, Regulation.

NY: Cambridge U. Press.

Yin, R.K. (2009). Case Study

Research: Design and

Methods, California,

USA: Sage Publications. 